\title{
Sectoral foresight in Poland: thematic and methodological analysis
}

\author{
Joanicjusz Nazarko, Urszula Glinska, \\ Anna Kononiuk and Lukasz Nazarko*
}

Faculty of Management, Bialystok University of Technology, ul. Wiejska 45A, 15-351 Bialystok, Poland

E-mail: j.nazarko@pb.edu.pl

E-mail: u.glinska@pb.edu.pl

E-mail: a.kononiuk@pb.edu.pl

E-mail: 1.nazarko@pb.edu.pl

*Corresponding author

\begin{abstract}
The aim of the paper is to propose a qualitative framework to the analysis of the Polish foresight projects based on the grounded theory. The dimensions of the analysis are: type of industry, aims and expected results, stakeholders, geographical distribution, time frame and the research horizon, applied methods, budget and funding sources. The study is supplemented by the findings on the foresight projects' impact on policy. Furthermore, the work sets the Polish sectoral foresights against the background of similar projects in other European countries. Based on the study the authors draw conclusions on the current and the potential future role of foresight studies in the development of the knowledge-based economy in Poland.
\end{abstract}

Keywords: sectoral foresight; foresight comparison framework; foresight in Poland; foresight impact; foresight evaluation.

Reference to this paper should be made as follows: Nazarko, J., Glinska, U., Kononiuk, A. and Nazarko, L. (2013) 'Sectoral foresight in Poland: thematic and methodological analysis', Int. J. Foresight and Innovation Policy, Vol. 9, No. 1, pp.19-38.

Biographical notes: Joanicjusz Nazarko is a Professor at the Bialystok University of Technology in Poland. He serves as Dean of the Faculty of Management and Head of the Department of Business Informatics and Logistics. He has published over 180 publications and a number of expert assessments, projects and technical and economic elaborations. $\mathrm{He}$ is a recognised expert in the field of forecasting, simulation, foresight and benchmarking. He was a member of The Steering Committee of the National Foresight Program 'Poland 2020'. He has served as an expert of the EU 7th Framework Program. He is an IEEE senior member.

Urszula Glinska is a Researcher at the Management Faculty of Bialystok University of Technology, Poland. She does research on social and cultural aspects of technological innovations. She teaches sociology and cultural anthropology to Polish and international students. She was a member of the Support Group of the National Foresight Program 'Poland 2020'. She is currently engaged in two foresight projects called 'Technological foresight, 'Technological Foresight (NT FOR Podlaskie 2020). Regional Strategy of Nanotechnology Development' and 'National Foresight Programme - Results Implementation'. 
Anna Kononiuk is a Researcher in the Chair of Business Informatics and Logistics at the Management Faculty of Bialystok University of Technology, Poland. She holds a $\mathrm{PhD}$ in Management from the Warsaw University. Her scientific research interests are: forecasting, time series analysis and foresight methods with the special emphasis on scenario analysis. She was one of the initiators of the Support Group in the National Foresight Program 'Poland 2020'. Currently, she is involved as a member of key research teams in projects called 'Technological Foresight (NT FOR Podlaskie 2020). Regional Strategy of Nanotechnology Development', 'National Foresight Programme - Results Implementation' and in other Polish foresight initiatives.

Lukasz Nazarko is a Researcher at the Management Faculty of Bialystok University of Technology, Poland. His academic interests focus on foresight and future studies, international trade, international organisations and transatlantic relations. He teaches economics and international financial institutions to Polish and international students. He was a member of the Support Group of the National Foresight Program 'Poland 2020'. He was a Visiting Research Associate at Tokyo University doing research on foresight and innovation policy. $\mathrm{He}$ is currently engaged in projects called 'Technological Foresight (NT FOR Podlaskie 2020). Regional Strategy of Nanotechnology Development', 'National Foresight Programme - Results Implementation' and in other Polish foresight initiatives.

\section{Introduction}

In the fast-developing world of growing complexity it is impossible to imagine distant future without the skilful processing and interpreting information coming from a variety of sources. Information about the future may be obtained via the traditional forecasting methods based on trend extrapolation. Unfortunately, being fixed in their assumptions, these methods often fail in the long-term perspective for the dynamism of political, economic, environmental, legal and demographic factors influencing predicted phenomena. A policy tool that enables to anticipate future from a very broad perspective is foresight. According to Kyriakou (2009), there are probably as many views of foresight as there are practitioners. One of the most quoted definitions was posited by Martin in 1985 who perceived foresight as "the process involved in systematically attempting to look into the longer-term-future of science, technology, the economy and society with the aim of identifying the areas of strategic research and the emerging strategic technologies likely to yield the greatest economic and social benefits". Another definition that is worth citing at length comes from a 'practical guide' produced for the FOREN Project sponsored by the European Commission. It set out to explore the scope of foresight application in a regional setting (Miles et al., 2008): "Foresight is a systematic, participatory, future intelligence gathering and medium-to-long-term vision building process aimed at present-day decisions and mobilizing joint actions" (Keenan and Miles, 2001).

According to the Polish Ministry of Science and Higher Education "foresight is a process of shaping the society's thinking about the future, in which scientists, engineers, business and public administration representatives take part in setting strategic directions of R\&D, with the aim of bringing the greatest economic and social benefits" (Jakuszewicz et al., 2006). 
Generally, in the existing published works, there could be distinguished the following forms of foresight projects (Tsoukas and Shepherd, 2004; UNIDO, 2004a, 2004b):

- $\quad$ national foresight revolving around setting desired visions of a given country development

- regional foresight aiming at anticipating the desired visions of a given region's development

- corporate foresight focusing on anticipating the desired visions of a given company

- sectoral foresight concentrating on anticipating the desired visions of a given sector.

Apart form the forms of foresight projects mentioned above, foresight research could be organised also at the supranational or transborder level or it could concern specific issues as in the case of British foresight projects (Keenan and Miles, 2001; Popper et al., 2007).

Foresight was introduced in Poland in the years 2003-2005 by the Ministry of Science and Informatisation which carried out the Pilot Foresight Program in the field of Health and Life. Based on the experiences of the USA, Japan and Western Europe, foresight was hoped to help build a 'culture of debating the future' in the Polish society and through that to substantially contribute to the economic and social transformation of the post-socialist states in Central and Eastern Europe (Okoń-Horodyńska, 2004). After the pilot project followed ten sectoral foresight exercises initiated mostly by higher education and research institutions. An important landmark in Polish foresight history was the National Foresight Program 'Poland 2020' (carried out from February 2006 to March 2009). The NFP 'Poland 2020' has ignited a considerable interest in foresight in academic, business and government circles. As a consequence, the second 'generation' of eleven sectoral foresight initiatives has been launched in Poland.

For the time being, the existing published works on Polish foresight initiatives comprise mainly interim and final reports on project results as well as publications aiming at presenting the methodology of foresight projects and the evaluation of foresight initiatives. The publications concerning methodological issues focus on presenting the role of scenario analysis in future anticipation (Kononiuk, 2010), the importance of unprecedented events (Kononiuk, 2009) and weak signals in risk management (Magruk, 2009), and the application of structural analysis for the classification of factors influencing regional nanotechnology development (Nazarko et al., 2011) to name but a few. The attempts of the National Foresight Program 'Poland 2020' evaluation may be found in publications of the Ministry of Science and Higher Education (MNiSW, 2009), the publications of the Forecasts Committee 'Poland 2000 PLUS' (Kleer and Wierzbicki, 2009), the study of Central Mining Institute (GIG, 2007) and publications on the role of Delphi method in the National Foresight Program 'Poland 2020' (Kowalewska and Głuszyński, 2009) and the role of the Support Group comprising young scientists in the same foresight exercise (Kononiuk et al., 2009). The attempts of evaluation of regional and sectoral foresight initiatives may be found in publications by Glinska et al. (2008) as well as Rogut and Piasecki (2011).

The paper attempts to make twofold contribution to the foresight debate. First, it succinctly presents Polish sectoral foresight projects to the international readership. In addition, it starts the discussion on the impact of Polish foresight initiatives and the sustainability of the foresight culture in Poland in the longer run. The sources of data for the study are: 
- questionnaires addressed to sectoral foresight project coordinators (prepared by the Support Group of The Polish National Foresight Program 'Poland 2020'1)

- questionnaires addressed to sectoral foresight project coordinators (prepared by the authors as a part of the study commissioned by the Ministry of Science and Higher Education)

- content analysis of projects' web pages.

Research for this paper has been carried out in three phases. The first phase was the collection of data from the project executors through questionnaires. The second phase was the collection and analysis of the information found on the websites of the sectoral foresight projects which were granted the financial support from the EU Operational Program 'Innovative Economy 2007-2013' (Priority 1: "Research and development of new technologies", Action 1.1.: "Support for scientific research for the building of knowledge based economy", Sub-action 1.1.1: "Research projects with the use of foresight method", Calls 1/2008 and 2/2008). In the third phase (second survey) the missing data as well as the information on the policy impact was derived.

Depending on data availability, some sections of the paper include the analysis of all 21 projects, other sections, in turn, concern only the first ten initiatives. It is authors' intention to continue monitoring the development of foresight application in Poland and to provide further and more complete analysis in the future as soon as the relevant data becomes available.

Until now, there have been twenty one projects of sectoral type undertaken in Poland (see Appendix A). It should be noted that as much as 7 out of 21 sectoral project exercises in Poland (more than 30\%) deals with the future of traditional branches of economy (coal, lignite and copper extraction, founding, wood industry). The thematic scope of the remaining projects corresponds to the top industries and technologies dealt with by the foresight exercises executed in Europe, i.e., environmental engineering, material engineering; electrical and electronic engineering; manufacturing engineering; biomedical engineering, manufacturing, electricity, gas and water supply, forestry (Popper et al., 2007). Project number 11 (Technological foresight 'NT FOR Podlaskie 2020'. Regional strategy of nanotechnology development) draws special attention. It is located in one of the least economically developed regions of Poland (and the European Union) with low levels of population's economic welfare, little business competitiveness and low innovation in the spheres of technology, processes and products. The project is based on the feed forward logic which assumes that the future changes of the environment will be effectively anticipated thanks to the project results. This should allow the region to chart the development trajectory which doesn't imitate others but heads in the direction where the leaders will be in the future.

\section{Sectoral foresight exercises carried out in Poland: a framework analysis}

The aim of the paper is to propose a qualitative framework to the analysis of the Polish foresight projects. It is generally acknowledged that there is no single universal foresight methodology applicable to every situation and context. Consequently, there may be no universal methodology of foresight comparison and benchmarking. Various studies offer models of foresight projects comparison oriented at foresight project objectives (Gavigan 
and Scapolo, 1999), foresight impact (Alsan and Oner, 2004) or both foresight process and impact (ForeTech, 2003). Widely referred to is also the Global Foresight Outlook (Popper et al., 2007).

The authors of the study have based the framework of the paper on the grounded theory posited by the Glasner and Strauss in 1967 (Singleton and Straits, 2005). This means, that before the study the authors did not have a priori assumptions about the final shape of the comparison framework. The framework has emerged in the course of the study drawing on the existing published works mentioned above and on the acquired data. As a result of this approach, the authors have developed a framework that is grounded in the context of a country with a short foresight history and a legacy of political, economic and social transformation. Authors believe it may serve as a basis of similar studies in other countries, especially in ones with similar socio-economic profile.

The authors were interested both in presenting a synthetic view on how, where and by whom sectoral foresight is done in Poland as well as in providing some insight into possible impact of the studied initiatives. The final framework has comprised:

- $\quad$ aims of the projects (both general and detailed)

- geographical distribution of projects' leading institutions in reference to the Polish regions

- $\quad$ stakeholders with reference to the percentage of actors involved representing different social groups

- $\quad$ time framework, i.e. the duration of the foresight initiative (in months)

- research horizon, i.e., how far into the future the project looks

- the research methods involved and their possible combinations

- $\quad$ projects' budget

- $\quad$ expected results (both formal and informal)

- degree of foresight influence on scientists, business world, politicians, state administration.

All sectoral foresight project (already completed or being currently carried out) are the subject of the analysis in this paper. The projects have been analysed and compared from the point of view of: aims, geographical distribution, stakeholders, time framework, research horizon as well as the methods used, project budget, expected results and perceived impact.

On the basis of the questionnaire data and the content analysis of the project web-sites one can distinguish the following aims (mostly of cognitive nature) common to all Polish sectoral foresight projects:

- assessment of sector's technological standing (assessment of raw materials availability and production methods used up to date)

- identification of solutions with the highest potential for development

- innovation assessment of chosen technologies 
- identification of key technologies of strategic importance for the sustainable development of the country

- identification of research directions and human resources development priorities for the purpose of the analysed technologies implementation

- creation of a strategic vision for future development of technologies.

More detailed aims of application or recommendation character may be spotted in two projects: Technological foresight in the area of polymer materials (project no. 2) and Development scenarios of metallic, ceramic and composite material technologies (no. 5).

Leading partners (i.e., coordinating institutions) of the sectoral foresight projects in Poland are mainly higher education and research institutions with Central Mining Institute in Katowice (Polish acronym: GIG) being the country leader in the number of coordinated foresight projects. Established in times of the centrally planned economy when heavy and extractive industries were seen as the main drivers of Poland's development, GIG presents a good example of a successful transition from a narrowly specialised institute of the past era into a dynamic, interdisciplinary research centre that possesses the key features of a knowledge-based organisation. Detailed listing of the project coordinators is presented in Appendix B. Figure 1 offers a view on the geographical distribution of project coordinators. Numbers in dark circles refer to the number of projects executed in a given region. Numbers in bright boxes refer to projects executed in a given region (numbering as it appears in Appendix A). While analysing the geographical distribution of projects' coordinators, it is noticeable that sectoral foresight projects are executed in less than a half of Polish provinces (i.e., 7 out of 16). Furthermore, there could be discerned two dominant tendencies, namely: on the one hand more than a half of project coordinators are clustered in two research centres, i.e., Mazovian and Silesian provinces, on the other hand, it is clearly visible that sectoral foresight projects are the most popular in the southern part of Poland.

Figure 1 Geographical distribution of the Polish sectoral foresight projects

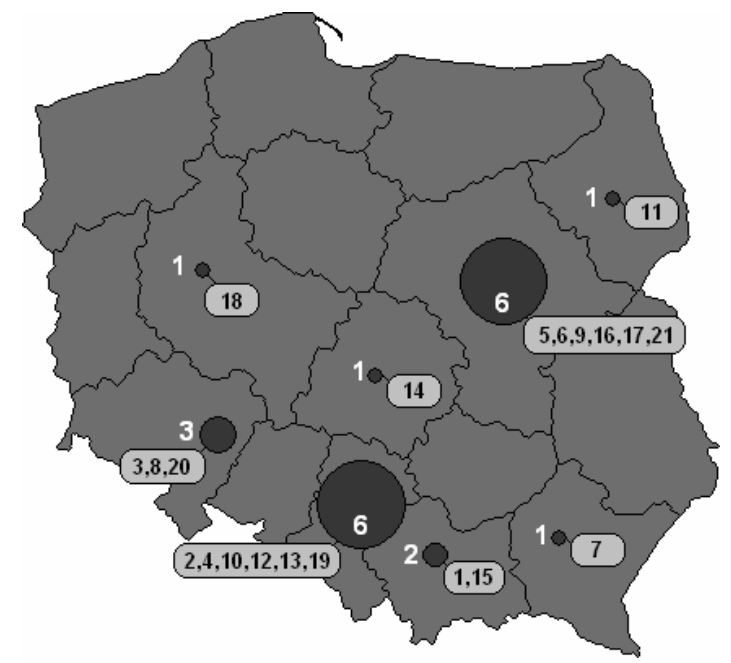

Source: Authors' own study 
Despite the fact that the ultimate target group and benefactors of the sectoral foresight projects should be by definition industry and enterprises, in Polish reality the majority of partner organisations involved in the foresight exercises are scientific and research institutions (Figure 2).

Figure 2 Summary of all partners involved in the sectoral foresight projects

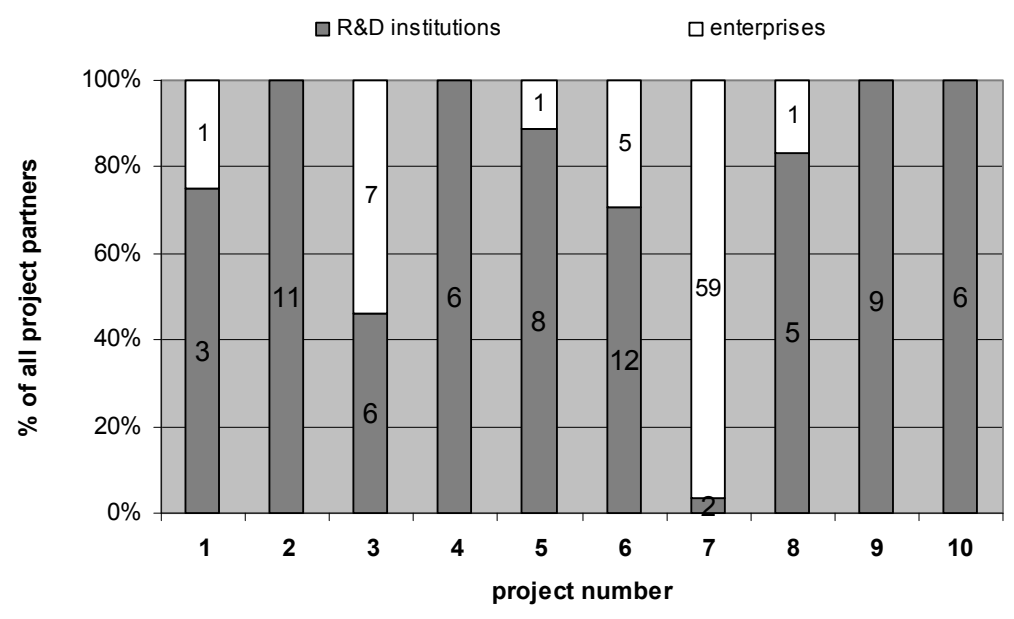

Source: Authors' own study

The questionnaire and websites from which the authors obtained the presented data did not offer any qualitative answers by the coordinators to the questions on the possible reasons for the domination of scientific units over business ones in almost all the projects. One may however assume that such a situation is caused by the low awareness of the possibilities of conducting foresight exercises in various sectors of economy as well as the doubt among entrepreneurs in the necessity or utility of such projects for their businesses. If this is really the case the Polish foresight initiatives run into the risk of becoming merely an occupation by the scientists and for the scientists, without the necessary transfer of the results to the industry.

The situation looks diametrically different in case of project no. 7: Directions of material technology development for the needs of aviation cluster 'Aviation Valley' where business units are the driving force of the initiative and the decisive number of partners are of business character. A considerable participation of enterprises in the sectoral foresight project is declared by the project no. 3: Technological development scenarios of the lignite extraction and processing industry. Also in projects no. 1: Technological foresight of Polish founding and no. 6: Assessment of the perspectives and benefits from the utilisation of satellite and cosmic technologies development in Poland more than $20 \%$ of partner organisations come from the industry.

Beside the task of charting development visions of certain technologies, foresight exercises have an important social aspect too. It means that development visions resulting from foresight initiatives are expected to be based on a social consensus. One way to achieve this is engaging representatives of those social groups which will be the beneficiaries of the foresight results. In case of sectoral foresight projects those key social groups are people from the business/industry. In this aspect the leading project is foresight no. 1: Technological foresight of Polish founding and foresight no. 7: Directions 
of material technology development for the needs of aviation cluster 'Aviation Valley'. In both projects $52 \%$ of people engaged in the foresight exercise come from the business/industry circles. For details see Figure 3.

Figure 3 Participation of business representatives and people under the age of 35

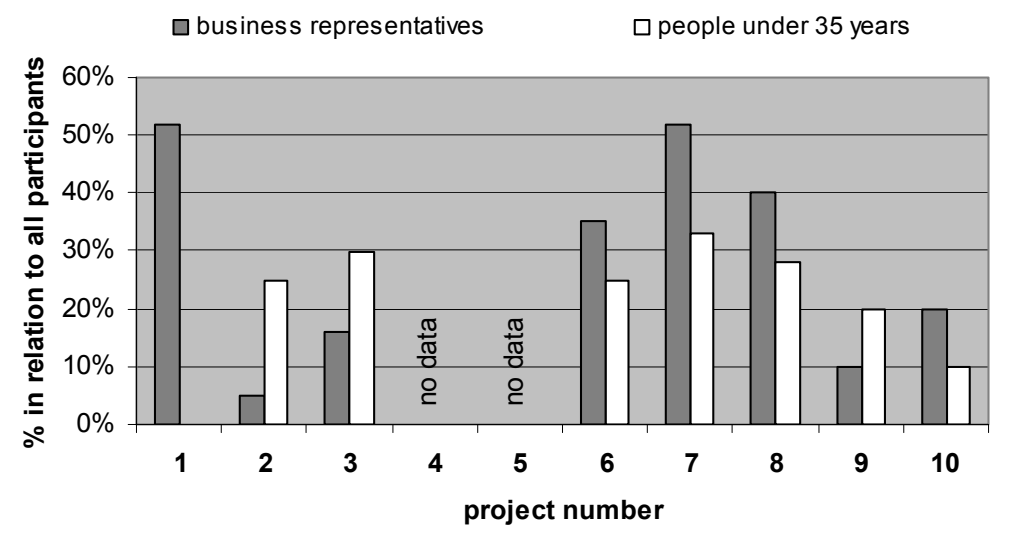

Source: Authors' own study

It is advisable that all foresight projects involve large groups of young people. Young people should always be seen as foresight stakeholders for they are the ones who will 'inherit' and live out the visions developed during the foresight projects. Figure 3 presents the ratios of young people's participation in sectoral foresight projects in Poland. According to the criteria of EU funding, young people are defined as those under the age of 35 years. Gathered data suggest that from all people actively involved in the sectoral foresight projects on average $30 \%$ are young people. Unfortunately many respondents omitted that question in the questionnaire hence the real ratio may be lower.

Figure 4 Time framework and research horizon of the sectoral foresight projects in Poland

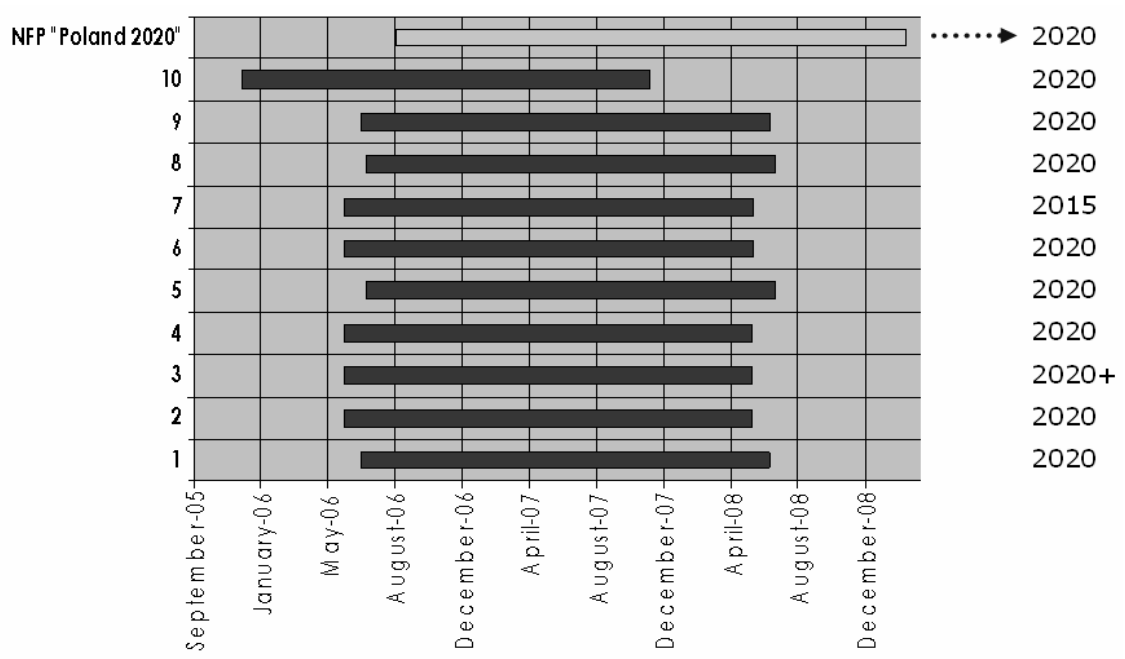

Source: Authors' own study 
Table 1 Methodology of sectoral foresight projects in Poland

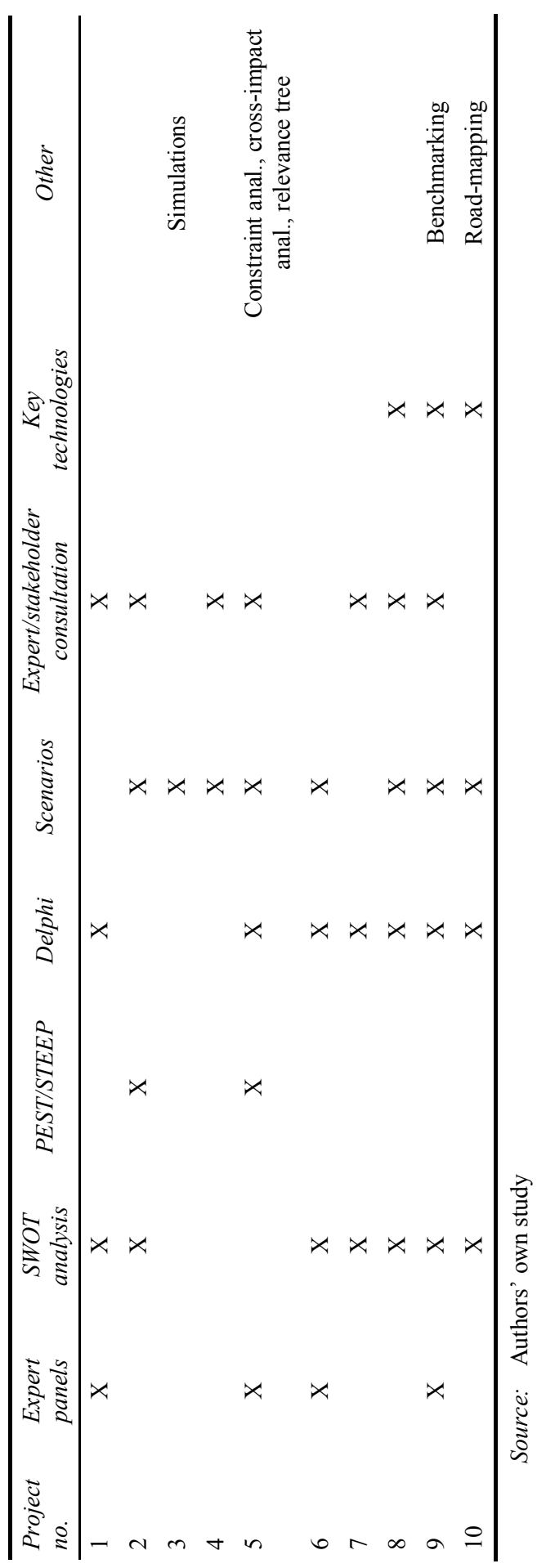


The first sectoral foresight exercise to be initiated in Poland was the project no. 10: Technological development scenarios of the fuel and energy complex for the country's energetic security which started in December 2005. Next nine projects took off almost parallel to each other in the first half of 2006 (Figure 4). Projects numbered from 1 to 10 finished in the first half of 2008. Projects numbers 11 to 21 are currently underway. Research horizon of the presented projects is predominantly year 2020 (similarly to the National Foresight Program 'Poland 2020' depicted for reference purposes in Figure 4). The only exception is foresight no 7: Directions of material technology development for the needs of aviation cluster 'Aviation Valley' whose research horizon is set on year 2015.

There is a substantial level of diversity among the methodological approaches to sectoral foresight among different projects in Poland. Majority of projects utilises classical foresight techniques like expert panels, SWOT analysis, Delphi method or scenarios of sector's development. Table 1 presents a detailed view of methods and techniques employed in the Polish sectoral foresight projects.

Less popular methods like constraint analysis, relevance trees or road-mapping were utilised in two instances i.e. project no 5: Development scenarios of metallic, ceramic and composite material technologies and project no 10: Technological development scenarios of the fuel and energy complex for the country's energetic security. The richest catalogue of used methods can be observed again in project no 5 and project no 8: Technological development scenarios of copper and accompanying raw materials extraction industry in Poland. Coordinators of project no 3: Technological development scenarios of the lignite extraction and processing industry have in turn decided to focus their methodology on two techniques: scenario analysis and simulation.

Organisational structures of Polish sectoral foresight exercises show a high level of similarity across all projects. Figure 5 presents a model that characterises the way sectoral foresight initiatives in Poland structure their work.

Figure 5 Typical structure of sectoral foresight exercise in Poland

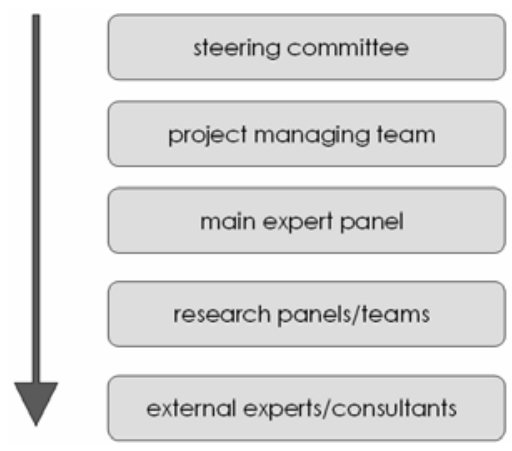

Source: Authors' own study

Steering committee oversees the realisation of a project and assures the proper quality of undertaken studies and processes. Project managing team reports to the steering committee. It coordinates the work of the main expert panel (which defines the work of other project's research teams), of any other research panels/teams and arranges the services provided by external experts/consultants. 
Total expenditures on sectoral foresight projects (completed and underway) in Poland amount to ca. 44 million PLN ( 1 EUR $\approx 4,0$ PLN). This is 11 times more than the budget of the National Foresight Program 'Poland 2020' (ca. 4 million PLN). Funding comes from three sources: partners' contributions, the Polish state budget and the EU funds. Figure 6 illustrates the budget size for each of 21 sectoral foresight initiatives. Furthermore, Figure 7 presents the proportions between funding sources in projects 1 to 10 (data for projects 7 and 10 does not differentiate between private and public funds).

Figure 6 Budgets of the sectoral foresight projects in Poland

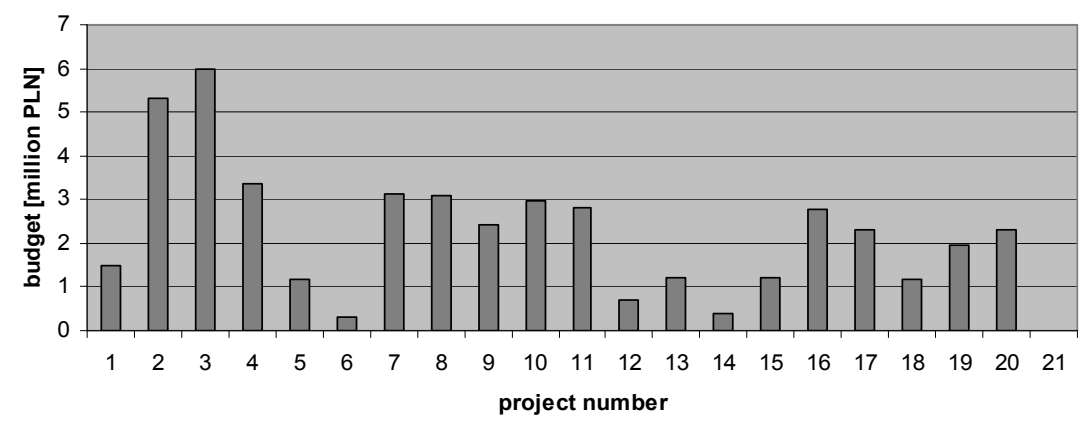

Source: Authors' own study

Figure 7 Proportions between sources of funding for the sectoral foresight projects in Poland

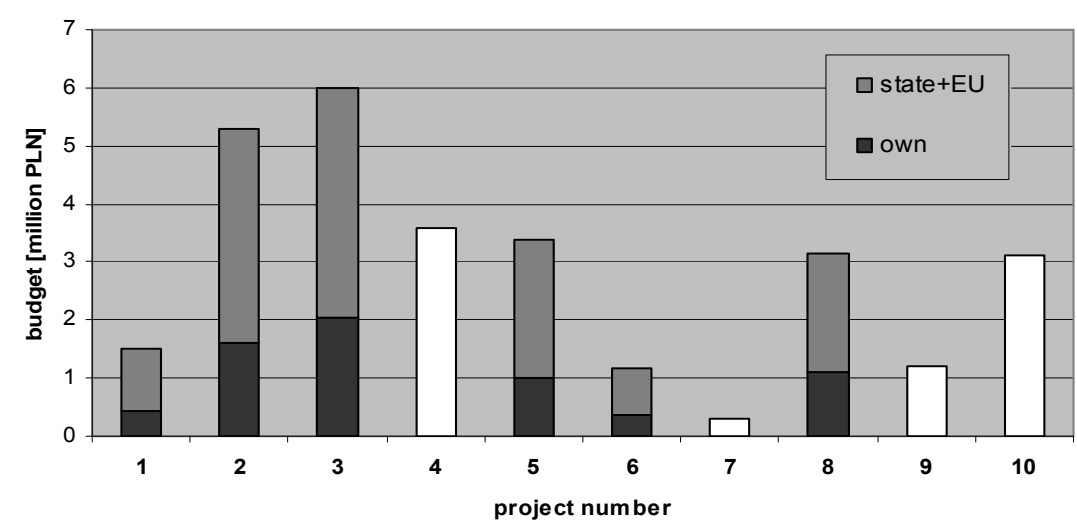

Source: Authors' own study

In Figure 6, two initiatives with high budgets stand out. These are projects no. 3: Technological development scenarios of the lignite extraction and processing industry and project no. 2: Technological foresight in the area of polymer materials. Foresight exercises with the smallest budgets are project 7: Directions of material technology development for the needs of aviation cluster 'Aviation Valley', project no. 14: Foresight of wood industry: research development scenarios in Poland until year 2020 and project no. 16: Thermonuclear energy foresight. The remaining projects enjoyed funding reaching from one million to three million PLN. Average size of a sectoral foresight budget in Poland is 2.2 million PLN. 
The most popular end product of the sectoral foresight projects in Poland is a final report. Based on the information obtained during authors' research one may point out the following elements of a final report present in the analysed foresight initiatives:

- $\quad$ mid- and long term development scenarios of selected technologies

- recommendations to businesses and research units on key areas of action from the market and scientific perspectives

- conditions for the development of a certain sector

- $\quad$ list and characteristics of factors determining future competitiveness of a certain sector in international markets

- $\quad$ principles of conducting monitoring of a certain technology

- road-maps for the development of a particular technology

- proposals regarding the forms of communication with the policy makers and stakeholders

- recommendations on the long term economic policy of the country and the criteria for funding research from the state budget.

As results of foresight initiatives carried out in Poland, databases on leading technologies and databases on experts from different sectors have been created. This can be seen as foresight's contribution to the creation of Poland's intellectual and social capital.

Another important aspect often brought up by the project coordinators is the task of popularising foresight attitude and future oriented thinking in the society. In case of Polish sectoral initiatives that aspect translated into papers, other publications, communiqués, presentations as well as seminars, workshops and conferences. It is worth noting that project no 6: Assessment of the perspectives and benefits from the utilisation of satellite and cosmic technologies development in Poland was especially active and productive in that sphere.

Foresight, understood as an instrument of future anticipation and policy support, is often criticised for its unclear impact in the relevant policy areas (innovation policy, science and technology policy, industrial policy, etc.). The research carried out by the authors doesn't give a definite answer to the question about the scope and the strength of foresight influence since a comprehensive foresight impact evaluation is a task which far exceeds the scope of this paper. What is presented here is the analysis of the subjective views of the foresight project leaders with respect to the impact of their initiatives. While such information should not be treated without some degree of reservation, it nevertheless sheds some light on how foresight and its impact are perceived in Poland.

A good entry point to explore the issue of foresight impact is the question about the existence of a body formally responsible for implementing the results of a particular foresight exercise. Out of 21 analysed project only four declared the existence of such institution. Almost all project leaders, however, claim very eagerly that there is a number of actors potentially interested in their exercises' results. They name: universities and R\&D institutions, national and regional authorities, companies, clusters, sectoral associations, NGOs, media, science and technology parks, business incubators, technology transfer centres. 
Foresight impact also depends on the way the results are disseminated. Polish sectoral foresight exercises do it mainly through websites, conferences, seminars, workshops, reports and publications. Surprisingly, media as a channel of communication with stakeholders is only mentioned twice.

The data presented in Figure 8 allows to draw interesting conclusions as to how Polish sectoral foresight project leaders perceive the impact of their initiatives on various groups of the stakeholders (' 0 ' meaning no influence and ' 5 ' indicating a very strong influence). Quite understandably, knowing the leading and partner institutions of various initiatives as well as the participants characteristics, the Polish scientific world is said to be the most influenced by foresight. In the second place comes the business world, which gives hope that sectoral foresight in Poland is not a pure academic exercise with no relevance to the country's economy. A worrying signal is a low impact that foresight seems to have on policy makers (national and regional administration) as well as the non-governmental sector.

Conducted survey also revealed that Polish foresight practitioners do not pay sufficient attention to the long term sustainability of their projects' results. When asked about that issue they responded in a very general manner, lacking concrete strategies and an action plans to make the results durable.

Figure 8 Impact of sectoral foresight on different stakeholder groups s as perceived by the project leaders

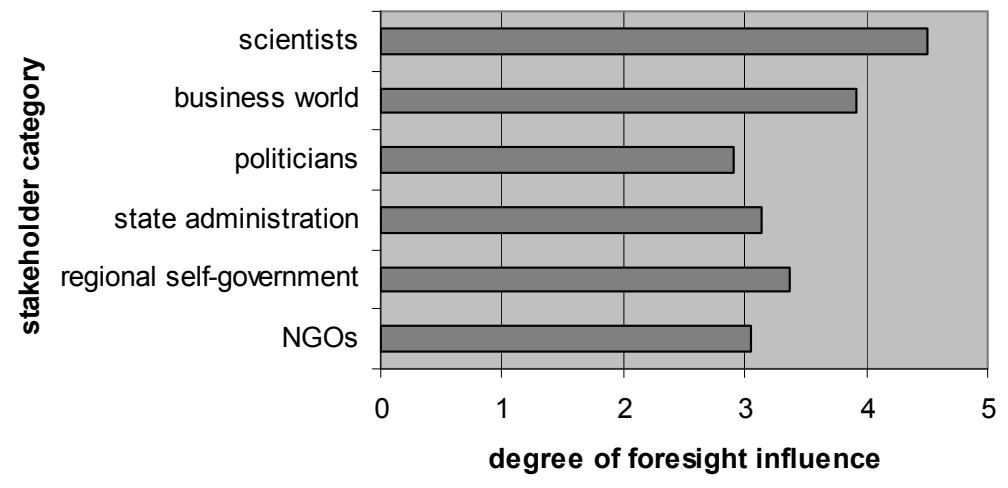

Source: Authors' own study

\section{Sectoral foresight in Poland and Europe}

Creating a full, up-to-date and reliable list of foresight initiatives carried out in Europe is definitely a difficult task. That challenge has been taken up by the EU-funded European Foresight Monitoring Network which since 2005 has been publishing Global Foresight Outlook (Popper et al., 2007) - a review of foresight initiatives in Europe and in selected countries of the world.

In spite of a multi-phased mapping process and continuously growing number of analysed projects (1,650 foresight initiatives in 30 countries were mapped in year 2007) it is quite obvious that Foresight Outlook does not reach every single foresight exercise that occur in monitored countries, Poland being an example of the above. Report identifies 
only 6 foresight projects while in 2007 there were 18 foresight initiatives underway (1 national, 9 sectoral and 8 regional). Nevertheless, a synthetic comparison of Polish sectoral foresight projects with European foresight initiatives (not only sectoral ones) registered by Foresight Outlook allows to draw some noteworthy conclusions.

Total of 21 sectoral foresight carried out places Poland below the level of European leaders. Although Foresight Outlook does not single out sectoral projects out of all mapped foresight initiatives one may assume that there is a rather similar proportion of sectoral foresight initiatives in all countries as compared to all foresight projects. This assumption allows to name the Netherlands (more than 250 foresight initiatives), Great Britain (more than 200), France (ca. 200), Germany (more than 100) and Finland (69) as the leaders of sectoral foresight in Europe.

According to the gathered data the following methods are used most frequently in the sectoral foresight exercises in Poland: scenario building ( $80 \%$ of the projects), SWOT analysis (70\%), Delphi method (70\%), expert and stakeholder consultations. All these four methods are among the 10 most popular foresight techniques applied in Europe. This leads to the conclusion that, as far as the methodology is concerned, Polish and European foresight initiatives show a high level of similarity.

Following are the 'hottest' foresight research areas in European foresight [according to the Frascati classification (OECD, 2007)]:

1 manufacturing

2 health and social work

3 electricity, gas and water supply

4 transport, storage and communication

5 public administration and defence

6 education

7 agriculture, hunting and forestry

8 community, social and personal service activities.

In-depth analysis points at more precisely defined research areas: environmental engineering, communication technologies, material engineering, electrical engineering, electronics, chemical engineering, biomedical engineering, biotechnology, climatology and other earth sciences, biochemistry, chemistry, animal and plant production, epidemiology, pharmacology.

It is easy to notice that the areas of research in Polish sectoral foresight projects only partly overlap with the areas listed above. There are two factors that contribute to that discrepancy. Firstly, the presence of themes connected to natural resources and their extraction is much stronger in Polish projects than in the European ones. Secondly, the presence of themes connected to biotechnology, nanotechnology or agriculture is much weaker in Polish projects than in the European foresight initiatives. It should be noted however that the second series of foresight projects that were initiated after the conclusion of the National Foresight Program 'Poland 2020' (projects nos. 11-21) concerned the research areas that are primarily convergent with the European foresight priorities and thus it has contributed to narrowing of the thematic gap between the Polish and the European foresight projects. 


\section{Discussion and conclusions}

Analysis of the gathered data on the sectoral foresight initiatives presented in this paper allows to formulate a number of remarks. They summarise the main findings from the study and present authors' views on the projects' significance.

- The number of sectoral foresight projects in Poland is relatively low compared to the European standards and taking into account the size of the country. This should be attributed to the very short history of foresight as an approach to future anticipation in Poland. However, there is a growing interest in foresight studies, especially among academia and policy makers. If this trend is sustained one may expect Poland to close the distance with Western Europe, at least with regard to the number of projects carried out.

- There are visible gaps in the research areas covered by the Polish sectoral foresight projects (e.g., biotechnology, climatology, chemistry). At the same time the traditional sectors of economy (founding, extraction of natural resources) occupy a very prominent place in Polish foresight research. That seems to be a negative feature that points at the relative backwardness of the Polish economy, however, one can imagine that foresight activity in the traditional branches results in creating some interesting specialisation niches for the Polish economy (e.g., modern and clean technologies based on coal).

- Public Research and Development units are the main initiators of sectoral foresight projects in Poland. Business and industry actors are a small minority among foresight partners. This point to the fundamental problem of weak links between the Polish academic world and the real economy. In the authors' opinion evoking interest in foresight among entrepreneurs is one of the key challenges that will determine the success or failure of foresight approach in Poland.

- Although at the level of partner institutions business and industry are a small minority the picture looks slightly better when the professional background of each person involved in the project is concerned. Significant participation of people with business background is an opportunity of strengthening the interrelation of scientific pursuits and the economic reality of the country.

- There is an uneven geographical distribution of sectoral foresight leaders in Poland. Southern Poland and Warsaw are clearly dominant when in comes to hosting foresight initiatives. Remaining parts of Poland are the home for just a few sectoral foresight projects. Such a distribution reflects to a large extent the disparities in economic and research potential between Polish provinces.

- Relatively high number of young participants of sectoral foresight projects in Poland is clearly a positive phenomenon as all future-oriented initiatives need to seriously take young voices into consideration. Pessimistic view, however, is that in the Polish context in which elderly males still occupy most important positions in academia, much space occupied by 'youth' may simply mean that the big players show their désintéressement with foresight. 
- There is a high variety of methods used in the Polish sectoral foresight exercises. Most frequently utilised are: SWOT analysis, Delphi method, scenario building and expert/stakeholder consultations. Compared with projects from other countries, Polish sectoral foresight studies use more methods in one project. In some cases, this results in a methodological mix-up with unclear connections between particular methods and difficulties with formulating results and translating them into action.

- Budgets of the Polish sectoral foresight projects are dominated by the EU funds. This points at the key role that the European Commission plays in developing a culture of forward-thinking in Poland. It remains uncertain however, if foresight enthusiasm has been planted deep enough to generate in the next years foresight initiatives based solely on the resources of Polish companies, R\&D entities and public authorities.

- Structure of all Polish sectoral projects draws from the European experiences and is divided into coordination-organisation pillar (steering committee, project managing team) and a content-conceptual pillar (panels, research teams, external experts).

- There is no sufficient attention paid to the issues of results dissemination, their impact and long term sustainability. Project leaders tend to focus on carrying out the project steps according to the schedule and then lose interest in the follow up. That creates the risk of foresight becoming a purely academic discipline detached from the policy action and the economic reality.

Presented paper shows that Poland is just beginning its journey towards a knowledgebased economy where foresight tools are used extensively to chart the future of sectors and technologies that are crucial for the long-term development of the country. The proposed framework for the analysis of sectoral foresight initiatives is rooted in Poland's experience but it may serve as a model for other countries. The results of the study are in a way an invitation to perform similar analyses elsewhere, especially in countries of Central Europe that share many common traits of their XX century's history. The presented study may serve as a basis for foresight initiative benchmarking and for the search of best practices in planning, running and evaluating sectoral foresight.

Sectoral foresight plays an important part in fostering communication between the worlds of science, politics, business and the society in general and thus contributes to the formation of an active and responsible Polish civil society. In the authors' view, this decade will show whether foresight becomes for good an integral element of Poland's national and regional innovation systems or whether it fades away deprived of the EU funding.

\section{References}

Alsan, A. and Oner, A. (2004) 'Comparison of national foresight studies by integrated foresight management model', Futures, Vol. 36, No. 8, pp.889-902.

ForeTech (2003) Framework for the Review of the Hungarian Foresight Programme and the Czech Foresight Programme, Technology and Innovation Foresight for Bulgaria and Romania (ForeTech), available at http://foretech.online.bg (accessed on 1 May 2009).

Gavigan, J.P. and Scapolo, F. (1999) 'A comparison of national foresight exercises', Foresight, Vol. 1, No. 6, pp.495-516. 
GIG (2007) Analiza tematyki projektów typu foresight prowadzonych w Polsce i ocena spójności ich planowanych wyników z zamierzeniami Projektu Foresight Polska 2020, Główny Instytut Górnictwa (Central Mining Institute), Katowice.

Glinska, U., Kononiuk, A. and Nazarko, L. (2008) 'Przegląd projektów foresightu branżowego w Polsce', Nauka i Szkolnictwo Wyższe, Vol. 32, No. 2, pp.60-73.

Jakuszewicz, I., Kononiuk, A., Magruk, A. and Nazarko, J. (2006) 'Inicjatywy foresight w Polsce i na świecie', in Kiełtyka, L. (Ed.): Multimedia $w$ organizacjach gospodarczych $i$ edukacji, Wyd, Difin, Warsaw.

Keenan, M. and Miles, I. (2001) A Practical Guide to Regional Foresight, Institute for Prospective Technological Studies, FOREN Network, Seville.

Kleer, J. and Wierzbicki, A. (2009) Narodowy Program Foresight Polska 2020: Dyskusja założeń scenariuszy, Polska Akademia Nauk. Komitet Prognoz, 'Polska 2000 Plus', Warsaw.

Kononiuk, A. (2009) 'Sposoby identyfikacji zdarzeń bezprecedensowych jako remedium na uniknięcie bądź łagodzenie skutków potencjalnego kryzysu', Prace i Materiały Wydziału Zarzqdzania Uniwersytetu Gdańskiego, Nos. 3/2, Sopot.

Kononiuk, A. (2010) 'Scenario analysis in future anticipation (in the light of the 'Polish National Foresight Programme 2020')', PhD thesis, Warsaw University, Warsaw.

Kononiuk, A., Magruk, A. and Nazarko, L. (2009) 'The concept of support group in the Polish National Foresight Programme 'Poland 2020', in Matwiejczuk, W. (Ed.): Zarzadzanie organizacja w nowej rzeczywistości gospodarczej: wybrane problem, Wyd, Diffin, Warsaw.

Kowalewska, A. and Głuszyński, J. (2009) Zastosowanie metody Delphi w Narodowym Programie Foresight 'Polska 2020', Pentor Research International, Warsaw.

Kyriakou, D. (2009) 'Book review', in Georghiou, L. et al. (2008) (Ed.): The Handbook of Technology Foresight, Edward Elgar Publishing, Inc. Northampton, MA, Technological Forecasting and Social Change, Vol. 76, p.258.

Magruk, A. (2009) 'Weak signals' w procesie zarządzania kryzysowego', Prace i Materiały Wydziału Zarzadzania Uniwersytetu Gdańskiego, Nos. 3/2, Sopot.

Martin, B. (1995) Technology Foresight 6: A Review of Recent Overseas Programmes, Office of Science and Technology, London.

Miles, I. et al. (2008) 'The many faces of foresight', in Georghiou, L. (Ed.): The Handbook of Technology Foresight. Concepts and Practice, Prime Series on Research and Innovation Policy, Edward Elgar Publishing, Inc. Northampton, MA.

MNiSW (2009) Wyniki Narodowego Programu Foresight 'Polska 2020', Ministerstwo Nauki I Szkolnictwa Wyższego, Warsaw.

Nazarko, J., Wnorowski, H. and Kononiuk, A. (2011) Analiza strukturalna czynników rozwoju nanotechnologii w województwie podlaskim, Oficyna Wydawnicza Politechniki Białostockiej, Bialystok.

OECD (2007) Revised Field of Science and Technology (FOS) Classification in the Frascati Manual, Organization for Economic Cooperation and Development.

Okoń-Horodyńska, E. (2004) 'Narodowy program foresight a foresight regionally', presentation at the seminar entitled Foresight Regionalny: Droga do Lokalnych Spoleczności Opartych na Wiedzy, 12 March, Krakow, Poland.

Popper, R., Keenan, M., Miles, I., Butter, M. and Sainz de la Fuenta, G. (2007) Global Foresight Outlook 2007, European Foresight Monitoring Network.

Rogut, A. and Piasecki, B. (2011) Podręcznik ewaluatora projektów foresight, Ministerstwo Nauki i Szkolnictwa Wyższego, Warsaw.

Singleton, R.A., Jr. and Straits, B.C. (2005) Approaches to Social Research, Oxford University Press, New York-Oxford.

Tsoukas, H. and Shepherd, J. (2004) Managing the Future, Foresight in the Knowledge Economy, Blackwell Publishing, Bodmin. 
UNIDO (2004a) Foresight Methodologies, Training Module 1, United Nations Industrial Development Organization, Vienna.

UNIDO (2004b) Foresight Methodologies, Training Module 2, United Nations Industrial Development Organization, Vienna.

\section{Notes}

1 Support Group was a team of young scholars from various universities and research institutions who were interested in the foresight topic - its concept, methodology, organization and application. The group's task was to assist the Steering Committee of the National Foresight Program 'Poland 2020' in the critical analysis and the continuous monitoring of program implementation. The authors were engaged in the work of that group.

\section{Appendix A}

Table A1 List of the sectoral foresight projects carried out in Poland and their sectors

\begin{tabular}{llc}
\hline No. & Project name & \multicolumn{1}{c}{ Sector } \\
\hline 1 & $\begin{array}{l}\text { Technological foresight of Polish founding } \\
2\end{array}$ & $\begin{array}{l}\text { Technological foresight in the area of polymer materials } \\
\text { Founding }\end{array}$ \\
3 & $\begin{array}{l}\text { Technological development scenarios of the lignite extraction and } \\
\text { processing industry }\end{array}$ & $\begin{array}{l}\text { Polymer materials } \\
\text { Lignite extraction }\end{array}$ \\
4 & $\begin{array}{l}\text { Technological development scenarios of the coal extraction } \\
\text { industry }\end{array}$ & Coal extraction \\
5 & $\begin{array}{l}\text { Development scenarios of metallic, ceramic and composite } \\
\text { material technologies }\end{array}$ & $\begin{array}{c}\text { Metallic, ceramic and } \\
\text { composite materials }\end{array}$ \\
6 & $\begin{array}{l}\text { Assessment of the perspectives and benefits from the utilisation of } \\
\text { satellite and cosmic technologies development in Poland }\end{array}$ & Cosmic technologies \\
7 & $\begin{array}{l}\text { Directions of material technology development for the needs of } \\
\text { aviation cluster 'Aviation Valley' }\end{array}$ & Aviation industry \\
8 & $\begin{array}{l}\text { Technological development scenarios of copper and } \\
\text { accompanying raw materials extraction industry in Poland }\end{array}$ & Copper \\
9 & $\begin{array}{l}\text { Monitoring system and development scenarios of medical } \\
\text { technologies in Poland }\end{array}$ & Medical technologies \\
\hline
\end{tabular}

Notes: ${ }^{a}$ In case of the project no. 9: Monitoring system and development scenarios of medical technologies in Poland the authors draw information about the project from GIG (2007)

Source: Authors' own study 
Table A1 List of the sectoral foresight projects carried out in Poland and their sectors (continued)

\begin{tabular}{|c|c|c|}
\hline No. & Project name & Sector \\
\hline 10 & $\begin{array}{l}\text { Technological development scenarios of the fuel and energy } \\
\text { complex for the country's energetic security }\end{array}$ & $\begin{array}{l}\text { Fuel and energy } \\
\text { industry }\end{array}$ \\
\hline 11 & $\begin{array}{l}\text { Technological foresight 'NT FOR Podlaskie 2020'. Regional } \\
\text { strategy of nanotechnology development }\end{array}$ & Nanotechnology \\
\hline 12 & Foresight of surface properties formation leading technologies & $\begin{array}{l}\text { Engineering and } \\
\text { biomedical materials }\end{array}$ \\
\hline 13 & $\begin{array}{l}\text { Technological foresight of public services development in Upper } \\
\text { Silesia Metropolitan Area }\end{array}$ & Public services \\
\hline 14 & $\begin{array}{l}\text { Foresight of wood industry: research development scenarios in } \\
\text { Poland until year } 2020\end{array}$ & Wood industry \\
\hline 15 & $\begin{array}{l}\text { Founding technologies foresight in the context of energy until year } \\
2030\end{array}$ & $\begin{array}{l}\text { Founding } \\
\text { technologies }\end{array}$ \\
\hline 16 & Thermonuclear energy foresight & Thermonuclear energy \\
\hline 17 & $\begin{array}{l}\text { Foresight of the priority and innovative technologies in } \\
\text { automation, robotics and measuring techniques }\end{array}$ & $\begin{array}{l}\text { Automation, robotics, } \\
\text { measuring techniques }\end{array}$ \\
\hline 18 & $\begin{array}{l}\text { Food and nutrition in the } 21 \text { century. A Vision for development of } \\
\text { the Polish food industry }\end{array}$ & $\begin{array}{l}\text { Nutrition and food } \\
\text { industry }\end{array}$ \\
\hline 19 & $\begin{array}{l}\text { Zero-emission energy economy in the conditions of the sustainable } \\
\text { development of Poland until year } 2050\end{array}$ & Power industry \\
\hline 20 & $\begin{array}{l}\text { Development strategy of power industry in Lower Silesia with use } \\
\text { of foresight methods }\end{array}$ & Power industry \\
\hline 21 & $\begin{array}{l}\text { Foresight of priority and innovative technologies of coal extraction } \\
\text { waste management }\end{array}$ & $\begin{array}{l}\text { Coal extraction, waste } \\
\text { management }\end{array}$ \\
\hline
\end{tabular}

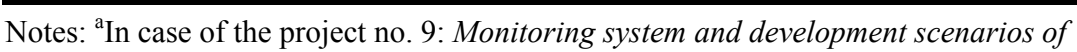
medical technologies in Poland the authors draw information about the project from GIG (2007)

Source: Authors' own study 


\section{Appendix B}

Table A2 Leading partners of the sectoral foresight projects in Poland

\begin{tabular}{llc}
\hline Project no. & Leading (coordinating) institutions & City \\
\hline $2,4,12,19$ & Central Mining Institute & Katowice \\
5 & $\begin{array}{l}\text { Institute of Fundamental Technological Research } \\
\text { (Polish Academy of Sciences) }\end{array}$ & Warsaw \\
6 & Space Research Centre (Polish Academy of Sciences) & \\
9 & Institute of Biocybernetics and Biomedical Engineering & Warsaw \\
& (Polish Academy of Sciences) & Warsaw \\
8 & KGHM CUPRUM Ltd Research and Development Centre & Wroclaw \\
3 & 'Poltegor-Institue' Institute of Opencast Mining & Wroclaw \\
1,15 & Foundry Research Institute & Cracov \\
7 & 'Aviation Valley' Association & Rzeszow \\
11 & Bialystok University of Technology & Bialystok \\
13 & The Silesian University of Technology & Gliwice \\
14 & Wood Technology Institute & Poznan \\
10 & Institute of Sustainable Technologies - National Research Institute & Radom \\
16 & Institute of Plasma Physics and Laser Microfusion & Warsaw \\
17 & Industrial Research Institute for Automation and Measurements & Warsaw \\
18 & The Research Institute of Pomology & Skierniewice \\
20 & Wroclaw University of Technology & Wroclaw \\
21 & Institute of Mechanized Construction and Rock Mining & Warsaw \\
\hline
\end{tabular}

Source: Authors' own study 